Original Article

\title{
Challenges of nanotechnology in cosmetic permeation with caffeine
}

\author{
Desafios da nanotecnologia na permeação cosmética com cafeína
}

\author{
E. M. Vogel ${ }^{a}$ (D), M. Bronoskia (i), L. L. M. Marques ${ }^{b}$ (D) and F. A. R. Cardoso ${ }^{a *}$ (1) \\ a Universidade Tecnológica Federal do Paraná, Programa de Pós-Graduação em Inovações Tecnológicas - PPGIT, Campo Mourão, PR, Brasil \\ ${ }^{\text {b} U n i v e r s i d a d e ~ T e c n o l o ́ g i c a ~ F e d e r a l ~ d o ~ P a r a n a ́, ~ D e p a r t a m e n t o ~ d e ~ E n g e n h a r i a ~ d e ~ A l i m e n t o s, ~ C a m p o ~ M o u r a ̃ o, ~ P R, ~ B r a s i l ~}$
}

\begin{abstract}
The evolution of beauty market and personal care is constant in Brazil as well in the rest of the world. Technological advances have brought up nanotechnology to the cosmetological field, employing active principles at atoms enveloped by vesicles, in order to take the active principle precisely to the target tissue to optimize the results achieved because of the considerable ease to cross skin barriers. Manufacturing of nanotechnology cosmetics is confronted with low absorption capacity. One of the many active principle found in cosmetic industry is caffeine, a pseudoalkaloid from the xanthine group used as a stimulant with the mechanism of the lipolytic action. This active is widely used in a esthetics and cosmetics field in treatments involving dysfunctions such as localized fat and fibroedema geloid. To work out perfectly, the principle active need to interact and create a set of factors that includes lipolysis intensification. The caffeine encapsulation in gel-based nanocosmetics has the purpose of taking this active up to the adipocyte, the target cell, for mentioned dysfunctions treatment. Thus, we aim to present a review of how has been, the use of caffeine in the production of cosmetics.
\end{abstract}

Keywords: nanotechnology, cosmetics, caffeine, permeation.

\begin{abstract}
Resumo
A evolução do mercado de beleza e cuidados pessoais é constante no Brasil e no resto do mundo. Os avanços tecnológicos trouxeram a nanotecnologia para o campo cosmetológico, empregando princípios ativos em átomos envolvidos por vesículas, a fim de levar o princípio ativo precisamente ao tecido alvo para otimizar os resultados alcançados devido à considerável facilidade de atravessar barreiras cutâneas. A fabricação de cosméticos nanotecnológicos é confrontada com baixa capacidade de absorção. Um dos muitos princípios ativos encontrados na indústria cosmética é a cafeína, um pseudoalocalóide do grupo xantina usado como estimulante no mecanismo da ação lipolítica. Este ativo é amplamente utilizado no campo da estética e dos cosméticos em tratamentos que envolvem disfunções, como gordura localizada e fibroedema gelóide. Para funcionar perfeitamente, o princípio ativo precisa interagir e criar um conjunto de fatores que inclui a intensificação da lipólise. 0 encapsulamento de cafeína em nanocosméticos à base de gel tem o objetivo de levar esse ativo até o adipócito, a célula alvo, para o tratamento de disfunções mencionado. Assim, objetivamos apresentar uma revisão de como tem sido o uso de cafeína na produção de cosméticos.
\end{abstract}

Palavras-chave: nanotecnologia, cosméticos, cafeína, permeação.

\section{Introduction}

Cosmetology has been one of the fastest growing cosmetic industry branches in the world today and one of the many factors driving the industry's advancement is investments in nanotechnology. The evolution of knowledge during the twentieth century brought significant changes to science and technology, where one of the key determinants for the technological transformation was the manipulation of the structure of matter at the atomic level, the nanotechnology (Bouchemal et al., 2004).

It is evident that the global market is going through periods of major scientific and technological competitions, especially after nanoscience and nanotechnology have been recognized as the trend in the 21 st century science and technology, which has led to an increase in world industry's human and financial resources, showing off evidencing industries' interested in technological innovations, manufacture of new products and diversified raw materials as a permeation and action mechanism (Durán et al., 2006).

Usually, nanotechnology means the ability to manipulate $1 \mathrm{~nm}$ range atoms in order to create larger structures with new structural mainframe and ordinarily for commercial

*e-mail: elianemvogel@hotmail.com; maricelibronoski@hotmail.com; leilamarques@utfpr.edu.br; reitz@utfpr.edu.br Received: 16 July 2020 - Accepted: 8 October 2020 
purposes. Nanotechnology is a set of actions of research, development and innovation that are obtained thanks to special properties of matter organized from structures of nanometric dimensions (Brasil, 2007; Antônio et al., 2014).

According to Borschiver et al. (2005) nanotechnology application cover practically all industrial and service sectors. The immense variety of use demands different areas of multidisciplinary competences in physics, chemistry, biology, material science and engineering, computing, among other areas aiming to extend human's capacity to manipulate matter to the limits of the atom.

Nanotechnology brought about a phase of technological convergence of great importance in human society, since its offshoots are present in most sciences. Several researchers argue that nanotechnology will be responsible for a technological leap, representing a new industrial revolution of knowledge (Martins, 2006; Toma, 2004; Schulz, 2009). Thus, the present study will address nanobiotechnology with the aim of constructing a new material at a molecular level and step up the research on the best way of nanoparticle permeation containing the active principle caffeine for fiberedema geloid treatment.

\section{General Considerations}

Today, nanotechnology presents itself as one of the most promising and attractive areas for technological development. The first approach to nanotechnology took place in 1959 when Richard Feynman reported in a lecture that man was capable of manipulating atoms to build new materials. The nano concept applied to technology first appeared with Norio Taniguchi in 1974, when it became possible to obtain materials at a nanometer level. Since then, more and more in-depth studies are being carried out, including nanoscience and nanotechnology in a multidisciplinary way (Marcone, 2015).

For Schulz (2009), nanoscience refers to the studies of phenomena and manipulation of materials at an atomic, molecular, and macromolecular scale, where properties differ from large scale. Nanotechnology refers to design, characterization, production and application of structures, equipment, and systems by shape and size nanometric scale control.

Nanotechnology and nanoscience $(N \& N)$ require systematic work and investment to improve techniques, both nationally and internationally. It is observed a relation between the evolution of this technology and government and private investments between 1991 and 2017, going from 167 to 113,000 published scientific papers.

In the year 2000, the $N \& N$ research structure started out in Brazil with the Nanobiotec, Nanomat, Renami and Nanosemiamat networks, all promoted by MCT-CNPq (Ministry of Science and Technology - National Council for Scientific and Technological Development). In 2001 the Millennium Institutes for Complex Materials, the Chip System Research Network, Microsystems and Nanoelectronics and the Multidisciplinary Polymeric Materials Institute, were created. In 2003, due to demands for scientific production and patents, the Nanoscience and Nanotechnology Development Program were implemented (Sant'Anna et al., 2013).
Private investments were incorporated into government agencies in 2005 to strengthen existing research centers. In 2012, the MCTI (Ministry of Science Technology and Innovation) (Brasil, 2012), through ordinance $n^{\circ} .245$ announced the National System of Nanotechnology Laboratories (SisNano) that would carry out activities in nanobiomagnetic, nanobiotechnology, carbon nanotubes, nanocosmetics, nanostructures, nanophotonics, molecular nanotechnology and nanobiostructures fields. In the year 2014, according to ANVISA (2014), cosmetics with nanotechnological characteristics amounted 599 products. Currently, it is estimated that by 2020 around US $\$ 3$ trillion will be invested in nanotechnology world-wide.

Cosmetology is the science that studies cosmetic products in all its aspects, as well as formula development, considering the compatibility between chemical compounds used and chemical, physical, biological, and microbiological tests required for product and user safety (Matos, 2014).

In Brazil, the Ministry of Health controls manufacturing and importation of all cosmetic products in order to ensure good quality and necessary safety for human consumption.

Regarding the meaning, cosmetics, hygiene products and perfumes are products comprising of natural or synthetic substances, for external use in different parts of the human body, skin, capillary system, nails, lips, external genitals, teeth, and mucous membranes of the oral cavity, with the sole or principal purpose of cleaning, perfuming, altering and correcting body odors and / or protecting or keeping them in good condition (Corrêa, 2012).

Nanotechnology used for the manufacturing and manipulation of drugs and cosmetics are known as drugdelivery systems, where active principles will be targeted and controlled release into the body with the advantage of protecting the agent from degradation, increasing solubility and bioavailability (Marcone, 2015).

For Vanzin (2015), cosmetic vehicles are pharmaceutical forms of different physical states with the objective to carry the active principle to the location in the body where it is supposed to operate. For this purpose, it is necessary that the vehicle does not inactivate the active principle during the application. In describing cosmetic vehicles within nanotechnology, liposomes, nanosomes, nanospheres, nanoparticles, nanocapsules, solid-lipid nanoparticles, nanoemulsions, microemulsions and niosomes are cited as main representatives.

Daudt et al. (2013) emphasize that liposomes and nanosomes have high biocompatibility because they are spherical vesicles, consisting of one or more concentric lipid bilayers, which isolate one or several internal aqueous compartments from the external environment, and are able to transport hydro and liposoluble substances. Their size is expressed in micros. Liposomes hae $10^{-6} \mu$ molecular weight while nanosomes have $10^{-9} \mu$.

In cosmetics, vehicles are used to increase the incorporation of active substances into cells, and they have high affinity for biological membranes for controlled release of active principles.

The advantage, in the usage of nanotechnology with liposomes is the permeation of the active principle with lower toxicity. In addition, cosmetics with liposomes 
are able to fuse to the skin and increase the absorption of active agents in the cutaneous tissue, all due to their biocompatibility (Matos et al., 2015).

The nanospheres or nanoparticles, in turn, consist of vesicles of thin biodegradable polymer shell and a central cavity with an oily nucleus in which the active agent is dissolved. They liberate the substance gradually and had greater stability reducing side effects (Zychar et al., 2016).

Nanocapsules are structured with a typical core and shell. Its active substances are transported inside a polymer cavity, adsorbed on the impregnated surface in the polymer matrix. In cosmetics, they are used to protect sensitive agents, to reduce undesirable odors and to prevent formulation incompatibility. They are believed to form a surface protection film and control the main agent penetration (Zychar et al., 2016).

According to Daudt et al.(2013), solid-lipid nanoparticles have excellent physical stability, ability to protect substances against degradation, release control, tolerability, ability to form a film on the skin and encapsulated substance permeation. They are suitable for water-based lipophilic substances. Their disadvantage is that they can maintain the encapsulation of the active principle and the physical instability.

As for nanoemulsions, they are composed of oil, water, and surfactant agents in droplets and have high kinetic stability. Their aqueous phase contains hydrophilic, pharmaceuticals, or cosmetic actives, and the oil phase is composed of mineral, silicone, vegetable oil, esters, or fatty acids. Among the advantages is the increase of skin hydration and its elasticity, active principle increased permeability and bettered skin spreadability (Zychar et al., 2016; Arantes et al., 2017).

Daudt et al. (2013) pointed out that microemulsions had low viscosity, they were transparent and thermodynamically stable; they increased hydrophilic and lipophilic substances permeation and are nanometric droplets, present in the most common sort of cosmetics.

For Zychar et al. (2016), the niosomes were considered as non-ionic vesicles, that is, with no dispersed charge in its aqueous phase that progressively altered the skin lipid barrier and combined one or more hydrophobic components with a hydrophilic group, improved stability and increased permeability.

Given these facts, all the innovation and technology described about "nano" pose a great challenge for cosmetic industry and researchers. Mainly regarding cosmetics development that uses controlled doses and are targeted exclusively to the intended location of action without accumulating in other tissues with possible adverse effects. And this adversity is related to the difficulty of permeation of active principles that must be absorbed through the skin.

As an example of a challenge faced by cosmetic industry, it can be cited the research work by AlvarezRomán et al. (2004) The researchers, using nonbiodegradable and fluorescent polystyrene 20 and $200 \mathrm{~nm}$ diameters nanoparticles, observed that the nanoparticles piled up notably in the follicular openings and that their distribution increased in a time-dependent manner. They also verified that the follicular location was favored by smaller size particles and that, regardless of the location, in the interfollicular region, also appeared nanoparticles, in surface images. However, in crosssectional images, it was observed that the skin structure between the follicles did not provide an alternative route of penetration for the polymeric vectors, whose transport was clearly prevented by the stratum corneum (AlvarezRomán et al., 2004).

The skin, in its turn, is part of the integumentary system, as well as secondary structures such as hair, glands and nails. Its main functions are providing protection against abrasion and harmful effect of ultraviolet irradiation; detecting heat, cold, tact, pressure, and pain; thermal regulation; vitamin D production for calcium homeostasis and excretion of metabolites by the glands (Vanputte et al., 2016). Divided into epidermis, dermis, and hypodermis (Figure 1), it can be better classified according to Table 1 .

It is known that the epidermis is virtually impermeable to any non-gaseous substance and its cutaneous permeability, described as the ability to selectively let pass certain substances according to their chemical nature. It is classified as 1 ) permeable skin: permeable to true gases and volatile substances which cross it by diffusion; 2) relatively permeable skin: permeable to certain liposoluble substances like steroid hormones, vitamin D and vitamin A, besides phenolic derivatives; 3 ) practically impermeable skin: impervious to electrolytes, proteins and carbohydrates. Salt permeation is negligible unless they are ionized (Harris, 2016).

According to Harris (2016), there are degrees of skin permeation in relation to skin types, such as lipid or alipic skin. Normally, lipid skins have a lower degree of permeation due to the obstruction of the pilosebaceous orifices by keratin and sebum, whereas in alipic skins, these holes are small or absent. Generally, the greater the skin hydration, including internal and external factors, better the active principles permeation.

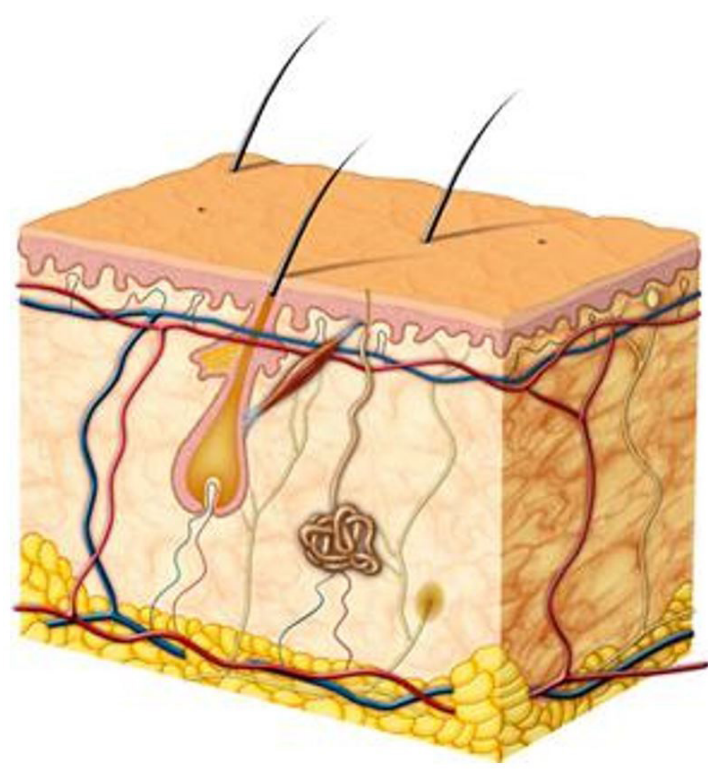

Figure 1. Human skin. Fonte: Vanputte et al. (2016). 
Vogel, E.M. et al.

Table 1. Comparison of skin (epidermis and dermis) and subcutaneous tissue.

\begin{tabular}{|c|c|c|}
\hline Part & Structure & Function \\
\hline Epidermis & $\begin{array}{l}\text { Outer layer of skin; stratified squamous } \\
\text { epithelium; composed of } 4 \text { or } 5 \text { strata. }\end{array}$ & $\begin{array}{l}\text { It prevents water loss and entrance of chemicals and } \\
\text { microorganisms; it protects against abrasion and } \\
\text { damaging effects of ultraviolet radiation; produces } \\
\text { vitamin D; it gives rise to hairs, nails, and glands. }\end{array}$ \\
\hline Stratum corneum & $\begin{array}{l}\text { Outermost stratum of the epidermis; } 25 \text { or } \\
\text { more layers of dead squamous cells. }\end{array}$ & $\begin{array}{l}\text { It provides structural resistance due to keratin in } \\
\text { cells; it prevents the water loss due to the lipids in } \\
\text { cells; desquamation of the most superficial cells } \\
\text { resists friction. }\end{array}$ \\
\hline Stratum lucidum & $\begin{array}{l}3 \text { to } 5 \text { layers of dead cells; seems transparent; } \\
\text { present on thick skin, absent on most of the } \\
\text { thin skin. }\end{array}$ & It disperses kerato-hyaline around the keratin fibers. \\
\hline Stratum granulosum & Two to five layers of flattened polygonal cells. & $\begin{array}{l}\text { It produces kerato-hyaline granules; lamellar bodies } \\
\text { release lipids from cells; dead cells. }\end{array}$ \\
\hline stratum spinosum & A total of 8 to 10 layers of multifaceted cells. & $\begin{array}{l}\text { It produces keratin fibers; lamellar bodies forming } \\
\text { inside keratinocytes. }\end{array}$ \\
\hline stratum basale & $\begin{array}{l}\text { Deepest stratum of the epidermis; a single } \\
\text { layer of cuboid or columnar cells; a basal } \\
\text { membrane of epidermis attached to the dermis. }\end{array}$ & $\begin{array}{l}\text { It produces cells from most of the surface strata; } \\
\text { melanocytes produce and supply melanin, which } \\
\text { protects the skin against ultraviolet radiation. }\end{array}$ \\
\hline Dermis & $\begin{array}{l}\text { Deeper portion of the skin; a connective tissue } \\
\text { composed of two layers. }\end{array}$ & $\begin{array}{l}\text { Responsible for structural resistance and flexibility } \\
\text { of the skin; epidermis exchanges gases, nutrients, } \\
\text { and waste with dermis blood vessels. }\end{array}$ \\
\hline Papillary layer & $\begin{array}{l}\text { It projects papillae towards the epidermis; } \\
\text { loose connective tissue. }\end{array}$ & $\begin{array}{l}\text { It assembles the blood vessels of the epidermis; } \\
\text { dermal papillae form fingerprints and footprints. }\end{array}$ \\
\hline Reticular layer & $\begin{array}{l}\text { Elastic and collagen fiber network; dense } \\
\text { irregular connective tissue. }\end{array}$ & $\begin{array}{l}\text { Dermis main fibrous layer; resistant in different } \\
\text { directions; form cleavage lines. }\end{array}$ \\
\hline Subcutaneous tissue & $\begin{array}{l}\text { It is not part of the skin; loose connective tissue } \\
\text { with abundant deposits of adipose tissue. }\end{array}$ & $\begin{array}{l}\text { It fixes the dermis to underlying structures; adipose } \\
\text { tissue provides energy storage, insulation, and } \\
\text { filling; blood vessels and nerves of the subcutaneous } \\
\text { tissue supply the dermis. }\end{array}$ \\
\hline
\end{tabular}

Source: Vanputte et al. (2016).

As for the penetration pathways, the transepidermal pathway, with a very slow penetration, stands out, but due to the great length of this organ (the skin), it is of considerable importance. It may be intercellular or transcellular, and the trans-adnexa route where the pilosebaceous or hair follicles are considered better penetrability zones, they make up about $1 \%$ (one percent) and are very important (Vanputte et al., 2016).

In addition to skin permeation, Borges and Scorza (2016) describe different factors that affect skin permeation:

\subsection{Biological/physiological}

- epidermis thickness: in hyperkeratotic skin, the permeability is hindered;

- age: due to thickening of the cornea layer and lack of hydration;

- blood flow: as the hyperemic skin becomes more permeable, the massaged actives can stimulate the absorption by circulation activation;

- hydration: the more hydrated the better the permeability;

- skin region: mucosa and regions with a large number of pilosebaceous or very vascularized orifices are more permeable;

- ability to associate with other substances;
- $\mathrm{pH}$ : the normal is approximately 5,0 (five); therefore acidic, when alkalinity causes a pH increase which, in its turn, increases skin permeability.

\subsection{Physical/chemical}

- improve skin permeability: low molecular weight, $\mathrm{O} / \mathrm{W}$ (oil/water) emulsion, ionization state of product to be applied (the active principle), principle active concentration, alcaline $\mathrm{pH}$, high temperature, hot and humid climate;

- penetration degree: it reaches the basal layer and the dermis reaches the connective tissue.

For the usage of a topical application product, it should be considered not only the concentration and pharmacological characteristics of the active principles, but also to the used vehicle, such as the stratum corneum, which is the main barrier to be overcome. It is also possible to use the permeation facilitators, which causes an increase of penetration, in the formulations. The main barrier to penetration is in the epidermis, specifically in the stratum corneum, which is constantly being renewed. Substances can penetrate through the epidermis, sweat glands, sebaceous and hair follicle, and a greater absorption happened through sebaceous glands and hair follicle (Harris, 2016). 
Table 2. Research involving nanocosmetics.

\begin{tabular}{|c|c|}
\hline Author & Search \\
\hline Touitou et al. (1994) & $\begin{array}{l}\text { Conducted research comparing the permeation of caffeine in carrier systems containing liposomes } \\
\text { versus systems containing substances that promote permeation, such as mixtures containing } 20 \% \\
\text { Transcutol and } 10 \% \text { oleic acid. The application of caffeine in aqueous solution containing these } \\
\text { substances resulted in a caffeine flow about } 40 \text { times greater than that obtained in its absence. } \\
\text { However, the greatest caffeine accumulation was obtained when the substance was conveyed in small } \\
\text { liposonic vesicles. }\end{array}$ \\
\hline Magalhães et al. (2013) & $\begin{array}{l}\text { They showed that caffeine is a plant extract that induces lipolysis. When it comes to natural assets, } \\
\text { instability is something that can hinder efficiency and accelerate the deterioration of the product. } \\
\text { Thus, nanoencapsulation represents a way to improve this condition. }\end{array}$ \\
\hline Marcato (2009) & $\begin{array}{l}\text { Expressed that the use of lipid nanostructures has several advantages compared to other colloidal } \\
\text { systems, such as greater biocompatibility, less toxicity, ease of production, greater stability during } \\
\text { storage and sterilization. }\end{array}$ \\
\hline Ereno (2008) & $\begin{array}{l}\text { Research showed a greater emphasis on cosmetics with differentiated action, such as nanocosmetics, } \\
\text { in which a more effective action was expected by the deeper penetration of particles into the skin and } \\
\text { without the risk of reaching the bloodstream, because when the molecules of the active ingredients in } \\
\text { creams are larger, they tend to remain on the surface of the skin, protecting it from water loss, having } \\
\text { a purely cosmetic effect. }\end{array}$ \\
\hline
\end{tabular}

Caffeine is an alkaloid of the xanthine group, which is found in some food such as coffee, tea, cola, guarana, mate, and commonly used as a stimulant with a lipolytic mechanism of action, phosphodiesterase and adenosine inhibitor and membrane receptors, Cyclic AMP messenger of lipolysis. It is indicated as an aid in the non-esthetic treatments of lipostrofia and LDG (cellulite). According to Technical Report $n^{\circ} .1$ of 29.06.2001 its concentration is $8 \%$ for gel-based cosmetics because it facilitates the incorporation into the formula (Gomes, 2013, Rodrigues et al., 2016).

Cosmetology has several active ingredients in the caffeine-derived forms, such as caffeine, cafeisilane c, cafeiskin, glycosan caffeine, isso-slim complex, micropatch caffeine, phytocafeil c plus, which operate similar to caffeine.

Fernandes et al. (2015) observed the caffeine precipitation in aqueous gels and discussed the phenomenon because it was slightly soluble in water and can caused lumps of hard redispersal, compromising effectiveness due to the concentration in the place of action.

The challenge of nanotechnology is to find a nano vector able to reach the adipocitary layer to potentiate localized fat and fibroedema geloid treatment.

\section{Methods and Material}

In order to highlight the perspective of nanotechnology in Brazil and examine the different ways of application in cosmetic branch, a bibliographical survey was carried out through articles, monographs and journals published between 2013 and 2017 in the Web of Science database and literature review in books such as Applied Cosmetology to Dermoesthetics (2010), Cosmetology Science and Technique (2012), Cosmetology (2013), Understanding Cosmeceuticals (2015), Skin (2016) and Anatomy and Physiology (2016). For the collection, nanotechnology, cosmetics, technology, nanocosmetics, caffeine and permeation were used as the main descriptors.

\section{Results and Discussions}

Although investments in nanoscience and nanotechnology in Brazil are modest compared with developed countries, the main challenges for innovation in nanotechnology are still making up production infrastructure, clinical trials, increased investment and nurturing research between universities and private companies with intellectual protection.

Researchers allude to several challenges that must be overcome so nanotechnology can be fully pulled ahead in society, highlighting the following: methods to evaluate the environmental exposure to nanomaterials; effective evaluation of nanomaterial toxicity; models to predict the potential impact of synthesized nanomaterials; ways of assessing the impact of nanomaterials throughout their lives spread; strategic programs to promote research into the risks of nanotechnology. Therefore, there are recommendations for improvement nanotechnology, specially studies of permeation using in vitro / in vivo models that guarantee the safe use of nanocosmetics; and nanotoxicity studies to ensure the safety of these materials to cosmetics industry workers, consumer, and environmental industries (Alvarez-Román et al., 2004; Guterres et al., 2007).

The main drawback of nanotechnology is still pointing each of the forms of "nano" the cell specification. In contrast, nanotechnology cosmetics have shown strong protection of active ingredients from chemical and enzymatic degradation, release control and low toxicity. Despite the apparent lack of success with results obtained with cosmetics and caffeine together, cosmetics industry increasingly seeks to develop nanotechnological cosmetic 
forms for use in cosmetic booths and home care as a way to potentiate their action in the target tissue.

People's high concern about improving physical appearance increasingly drives the cosmetic industry to develop highly differentiated products positive to the end consumer, respecting regulations and standards of each country, environmental impacts, ethics and economics. Mandelbaum (2011) claim that one lives in a society where "the cult of the body and perfect shape" is valorized and encouraged, where people often appreciate appearance more than ethics and human values. Worrying about appearance is, in fact, so relevant in today's society that it preys on people's mind, increasingly tying in the body image to the self-identity. Beauty measures are related to cultural and social values, and contemporary society has determined that beauty is related to youth.

The multifactorial framework evaluation involving localized fat and fibroedema geloid brings up the need of a treatment in association with specific actives to achieve desired results. The substantial number of treatments and cosmetics with potential lipolytic activity of caffeine available on the market are often unpredictable, with little information on labeling and lack of significant evidence of active permeation level, as shown in Table 2 .

The predominant difference in the application of nanotechnology is to enhance physical properties and chemical concentrations in extremely low concentrations and confer characteristics previously not presented by a given product. This is due to the nanometric dimensions, which offer a higher surface area, greater degree of dispersion and features that are size dependent upon the structure.

\section{Conclusion}

To understand the occurrence of adipocyte accumulation and fibroedema geloid (FEG), one has to have a thorough knowledge of the subcutaneous tissue, although there are a lot of biochemical reactions that have not been fully elucidated, along with the mechanism of action of caffeine. Cosmetology has a great influence over the processes of adipogenesis, lipogenesis and lipolysis.

The changes in the set of degenerative and progressive effects that occur in the subcutaneous tissue and skin texture, by considering its variation as a pathology, and not as an appearance of unaesthetic skin, it is of utmost importance to treat this alteration, a part from, knowing how to avoid its triggering factors.

It is important to note that cosmetic actives' anticellulite mechanisms of action need to interact and create a set of factors that include antioxidants, antiinflammatory mechanism of action, reverse edema, improve microcirculation, repair of tissues and intensifying lipolysis with higher nanocosmetic intensity.

There are still a limited study on the action of caffeine formulated with nanotechnology and its exact mechanisms of permeation, there is a urgent need for more scientific studies and more detailed case studies.

\section{References}

AGÊNCIA NACIONAL DE VIGILÂNCIA SANITÁRIA - ANVISA. Diagnóstico institucional de nanotecnologia. Brasília: ANVISA, 2014.

ALVAREZ-ROMÁN, R., NAIK, A., KALIA, Y.N., GUY, R.H. and FESSI, H.. 2004. Enhancement of topical delivery from biodegradable nanoparticles. Pharmaceutical Research, vol. 21, no. 1, pp. 18181825. http://dx.doi.org/10.1023/B:PHAM.0000045235.86197. ef. PMid:15553228.

ANTÔNIO, J.R., ANTÔNIO, C.R., CARDEAL, I.L.S., BALLAVENUTO, J.M.A. and OLIVEIRA, J.R., 2014. Nanotechnology in dermatology. Anais Brasileiros de Dermatologia, vol. 89, no. 1, pp. 23-25. http:// dx.doi.org/10.1590/abd1806-4841.20142228. PMid:24626657.

ARANTES, P.O., SANTOS, Q.N., FREITAS, Z.M.F., PYRRHO, A.S., CERQUIRA-COUTINHO, C., VILLA, A.L.V., SANTOS, E.P. and RICCI-JÚNIOR, E., 2017. Promotion of cutaneous penetration of nifedipine of nanoemulsion. Brazilian Journal of Pharmaceutical Sciences, vol. 53, no. 2, pp. 1-12. http://dx.doi.org/10.1590/ s2175-97902017000215249.

BORGES, F.S. and SCORZA, F.A. Terapêutica em estética: conceitos e técnicas. São Paulo: Phorte, 2016.

BORSCHIVER, S., GUIMARÃES, M.J.O.C., SANTOS, T.N., SILVA, F.C. and BRUM, P.R.C., 2005. Patenteamento em nanotecnologia: estudo do setor de materiais poliméricos nanoestruturados. Polímeros, vol. 15, no. 4, pp. 12-16. http://dx.doi.org/10.1590/ S0104-14282005000400007.

BOUCHEMAL, K., BRIANÇON, S., PERRIER, E. and FESSI, H., 2004. Nano-emulsion formulation using spontaneous emulsification: solvent, oil and surfactant optimisation. International Journal of Pharmaceutics, vol. 280, no. 1-2, pp. 241-251. http://dx.doi. org/10.1016/j.ijpharm.2004.05.016. PMid:15265563.

BRASIL. Ministério da Ciência e Tecnologia - MCTI. Portaria n ${ }^{\circ} 245$, de 5 de abril de 2012. Diário Oficial da República Federativa do Brasil, Brasilia, 9 abril 2012, no. 68, Seção 1, pp. 5.

BRASIL Ministério da Saúde. Agência Nacional de Vigilância Sanitária. 2007. Resolução RDC nº 67, de 8 de outubro de 2007. Aprova o regulamento técnico sobre boas práticas de manipulação de preparações magistrais e oficinais para uso humano em farmácias. ANVISA: Brasília, DF. Available from: www.anvisa.gov.br.

CORRÊA, M.A. Cosmetologia: ciência e técnica. São Paulo: Medfarma, 2012.

DAUDT, R.M., EMANUELLI, J., KÜLKAMP-GUERREIRO, I.C., POHLMANN, A.R. and GUTERRES, S.S., 2013. Nanotecnologia como estratégia para o desenvolvimento de cosméticos. Ciência e Cultura, vol. 65, no. 3, pp. 32-38. http://dx.doi.org/10.21800/ S0009-67252013000300011.

DURÁN, N., MATTOSO, L.H.C. and MORAIS, P.C. Nanotecnologia: introdução, preparação e caracterização de nanomateriais e exemplos de aplicação. São Paulo: Artliber, 2006.

ERENO, D., 2008. Beleza fundamentada. Revista Pesquisa FAPESP, vol. 146, pp. 80-86.

FERNANDES, E.M., DAMASCENO, G.A.B., FERRARI, M. and AZEVEDO, E.P., 2015. Incremento na dissolução da caffeine em base de ammonium acryldimethyltaurate/vp copolymer: desenvolvimento farmacotécnico de géis anti-celulite. Revista de Ciências Farmacêuticas Básica e Aplicada, vol. 36, no. 1, pp. 69-75.

MATOS, B.N., OLIVEIRA, P.M., AREDA, C.A., CUNHA-FILHO, M.S.S., GRATIERI, T. and GELFUSO, G.M., 2015. Preparações farmacêuticas e cosméticas com uso de nanotecnologia. Brasília Med, vol. 52, no. 1, pp. 8-20.

GOMES, R.K. Cosmetologia: descomplicando os princípios ativos. São Paulo: L\&PM, 2013. 
GUTERRES, S., ALVES, M.P. and POHLMANN, A.R., 2007. Polymeric nanoparticles, nanosphere 377 and nanocapsules, for cutaneous applications. Drug Target Insights, vol. 2, pp. 147-157. http:/ dx.doi.org/10.1177/117739280700200002. PMid:21901071.

HARRIS, M.I.N.C. Pele: do nascimento à maturidade. São Paulo: Senac, 2016.

MAGALHÃES, B.H., CAMARGO, M.F. and HIGUCHI, C.T., 2013. Indicação de uso de espécies vegetais para o tratamento da celulite com fins cosméticos. InterfacEHS, vol. 8, pp. 61-82.

MANDELBAUM, M.H.S. Tratado de medicina estética. São Paulo: Roca, 2011.

MARCATO, P.D., 2009. Preparação, caracterização e aplicações em fármacos e cosméticos de nanopartículas lipídicas sólidas. Revista Eletrônica de Farmácia, vol. 6, no. 2, pp. 1-37. http:// dx.doi.org/10.5216/ref.v6i2.6545.

MARCONE, G.P.S., 2015. Nanotecnologia e nanociência: aspectos gerais, aplicações e perspectivas no contexto do Brasil. Perspectivas da Ciência e Tecnologia, vol. 7, no. 2, pp. 23-28.

MARTINS, P.R. Nanotecnologia, sociedade e meio ambiente. São Paulo: Xamã, 2006.

MATOS, S.P. Cosmetologia aplicada. São Paulo: Érica, 2014.

RODRIGUES, F., ALVES, A.C., NUNES, C., SARMENTO, B., AMARAL, M.H., REIS, S. and OLIVEIRA, M.B., 2016. Permeation of topically applied caffeine from a food by-product cosmetic formulations: is nanoscale in vitro approach na option? International Journal of Pharmaceutics, vol. 513, no. 1-2, pp. 496-503. http://dx.doi. org/10.1016/j.ijpharm.2016.09.059. PMid:27662805.

SANT'ANNA, L.S., ALENCAR, M.S.M. and FERREIRA, A.P. Patenteamento em nanotecnologia no Brasil: desenvolvimento, potencialidades e reflexões para o meio ambiente e a saúde humana. Química Nova, vol. 36, n. 2, pp. 8-13, 2013.

SCHULZ, P.A.B. A encruzilhada da nanotecnologia: inovação, tecnologia e riscos. Rio de Janeiro: Vieira \& Lent, 2009.

TOMA, H. O mundo nanométrico: a dimensão do novo século. São Paulo: Oficina de Texto, 2004.

TOUITOU, E., LEVI-SCHEFFER, F., DAYAN, N., ALHAIQUE, F. and RICCIERI, F. Modulation of caffeine skin delivery by carrier design: liposomes versus permeation enhancers. International Jounal Pharmaceutics, vol. 103, pp. 131-136, 1994.

VANPUTTE, C., REGAN, J. and RUSSO, A. Anatomia e fisiologia de Seeley. Porto Alegre: AMGH, 2016.

VANZIN, S.B. Entendendo cosmecêuticos: diagnósticos e tratamentos. São Paulo: Santos, 2015.

ZYCHAR, B.C., KATAOKA, V.Y. and AUDI, C., 2016. Prospecção da nanotecnologia cosmética no setor da estética e suas principais nanoestruturas. Atas de Ciências e Saúde, vol. 4, no. 4, pp. 18-25. 